\title{
Analysis of Gender Difference on Online Shopping Lifestyle at Padang City
}

Wiry Utami ${ }^{1 *}$,

Linda Wati ${ }^{2}$,

Listiana Sri Mulatsih 3,

Department of Management, Faculty of Economics and Business, Universitas Bung Hatta, Padang, Sumatera Barat.

\section{ARTICLE INFO}

ISSN: $2723-1097$

Keywords:

Gender, lifestlyle, online shooping,

\section{ABSTRACT}

This study aimed to examine the gender difference between men and women in online shopping lifestyle at Padang City. This type of research is comparative study, carried out to compare the similarities and differences of two or more the fact and object properties in the framework based on certain carefully. The technique of taking sample is by using purposive sampling. Total sample in this study is 100 consist of 50 men and 50 women. The samples in this study were men and women consumers who have shopped online for at least the last six month. Data collection uses questionnaire and analysis methods using independent sample t-test. The result of this study show that there are no differences between men and women in online shopping lifestyle at Padang City.

\section{Introduction}

Online shopping behaviour refers to the process of purchasing products and services over the internet. Online shopping has become an alternative to buying products and services. Online sales have been growing both in terms of service, effectiveness, security, and popularity. In this day, online shopping is preferred because consumers do not need to spend a lot of energy when shopping online. They can browse the items just by looking at the website and they can directly make a purchase transaction. Online shopping is a place to purchase goods and services through the Internet, which is a form of electronic commerce (e-commerce) that is used for seller-to-seller or seller-to-consumer transaction activities. The substantial growth and steady increase of online sales stimulate great interest in understanding what impacts people's decisions to participate in or refrain from shopping online (Shih, 2004).

Furthermore, online shopping grows and develops into a modern habitual activity among the peoples. According to Lestari,(2015) online shopping is a shopping activity that provides lifestyle changes for the community. Online

Journal of Business and Management Review Vol. 2 No. 82021 Page 569-579

DOI: $10.47153 /$ jbmr28.2022021

*Corresponding Author

Email address: wiryutami@bunghatta.ac.id 
shopping changes people's activities from offline or conventional into online. Online shopping is considered as a solution for changing people's lifestyles that demand faster, practical and easier things. Lifestyle is a person's way of life to spend time (activities) that they consider important in their environment and what they think about themselves and the environment around them (Fatmawati, 2020).

In marketing, lifestyles are named psychographics, which include consumers activities, interests, and opinions (Schiffman \& Wisenblit, 2019). According to Kotler \& Keller, (2016) a lifestyle is a person's pattern of living in the world as expressed in activities, interests, and opinions. So, online shopping lifestyle can be seen from the activities, interests and opinions of consumers. The way of life carried out by each community usually varies depending on daily activities, both due to needs and the influence of the surrounding environment which includes family, work, community, business, politics, education and the future (Fatmawati, 2020).

In online shopping, gender factors can affect shopping activities. Lifestyle and gender are important factors in online shopping behaviour. Nowadays, both men and women love to shop online. Especially during pandemic, people prefer to shop online rather than shop offline. The presence of several sites that are used for online shopping has changed people's lifestyles, which used to be offline to online. All necessity that consumers need are now easily obtained by online shopping.

Even though, gender equality is always upheld by society, even men and women are considered to have the same ability in deciding to shop online, but several studies have shown that gender is an important factor that can influence consumers in online shopping behavior (Prabowo \& Suwarsi, 2009). Several studies have also found differences in the number of products or services purchased online between male and female buyers (Lim et al., 2010). While, studies of online shopping attitude are widespread in the literature, studies of gender differences in online shopping attitude are scarce and reported findings are inconsistent (Dittmar et al., 2004; Hasan, 2010). Gender is the factor that distinguishes the frequency of online purchases (Sudjanarti et al., 2018). This is supported by Rodgers \& Harris, (2003) that the number of Internet users is equally divided among the genders, more men than women engage in online shopping and make online purchases.

According to Zhou et al., (2007) suggest three explanations for gender differences in online shopping. First, women's shopping orientation is different from that of men. While men prefer convenience over social interaction, women are more motivated by emotional and social interaction. Thus, the lack of face-to-face communication or social interaction offered by online shopping may deter more women than men from shopping online (Dittmar et al., 2004). Second, the types and characteristics of products that are available on online seem to favour males (Slyke et al., 2002). Products that are more associated with men such as computers and electronics are amply available and can be easily purchased online. Whereas products that are more associated with females such as food, home decor, and 
clothing may not be widely available online. Thus, women may view online shopping as less compatible and less accommodating than conventional shopping. Finally, women prefer and enjoy physical evaluation of products such as seeing and feeling the product before they buy it (Dittmar et al., 2004).

Furthermore, literature reviews of online shopping indicate that results concerning gender differences in online shopping environments are mixed and inconsistent (Chang et al., 2005; Zhou et al., 2007). As a result, little is known about males and females perceptions of online shopping and what impacts men's and women's decision to engage in or abstain from online shopping (Cyr \& Bonanni, 2005). According to Chang et al., (2005) shows that more men than women buying online in some studies and no significant gender differences in online shopping behaviour between the genders in other studies. Likewise, according to Zhou et al., (2007) demonstrates conflicting findings pertaining to the impact of gender on online shopping activities. Thus, gender differences in online shopping lifestyle deserve more attention and better understanding. So, there are still inconsistent result about online shopping lifestyle between men and women, so in this study interested in conducting different tests of lifestyle between men and women in online shopping. Therefore, based on the explanation, this study examined different test of gender between men and women on online shopping lifestyle at Padang City

\section{Literature Review}

\section{Consumer Behavior}

Consumer behavior is essentially to understand why consumers do and what they do. Consumer behavior is the study of consumers choices during searching, evaluating, purchasing, and using products and services that they believe would satisfy their needs. Marketers uncover consumer desires that are partially satisfied by the products available, and create and promote superior offerings. Consumer behavior explains how people decide to spend their money, time, and effort.. Marketers offer for sale and describes which products and brands consumers select and why, when and where they purchase them (Schiffman \& Wisenblit, 2019). Consumers have an interesting diversity to study because it includes all individuals of various ages, cultural backgrounds, education, and other socio-economic conditions. Therefore, it is very important to study how consumers behave and what factors influence this behavior.

Acoording to Kotler \& Keller, (2016), consumer behavior is the study of how individuals, groups, and organizations select, buy, use, and dispose of goods, services, ideas, or experiences to satisfy their needs and wants. Marketers must fully understand both the theory and the reality of consumer behavior. Consumer behavior influenced by cultural, social, and personal factors. Of these, cultural factors exert the broadest and deepest influence (Kotler \& Keller, 2016). According to Daryanto \& Ismanto, (2014) states that consumers buy product and service to satisfy 
their various wants and needs. The product and services are not as important as the human needs and desires that they fulfil, but because these goods are considered capable of fulfilling the needs they want. Thus, what consumers buy is not the goods themselves, but the uses that the goods can provide, or in other words, the ability of these goods to fulfil their needs and wants. Consumer behavior is the behavior shown by consumers in searching for, buying, using, evaluating, and discontinuing consumption of products, services and ideas.

According to Kotler \& Keller, (2016), there are several factors that influence consumer behavior are cultural factors, social factor, personal factors and psychological factors. Culture is the fundamental determinant of a person's wants and behavior. Cultural factors have a broad and deep influence on consumer behavior. Cultural factors consist of: culture, sub-culture, social class, each culture consists of smaller that provide more specific identification and socialization for their members. Subcultures include nationalities, religions, racial groups, and geographic regions. Then, social factor is a consumer's behavior is influenced by social factors such as reference groups, family and social status. Personal factor is personal characteristics that influence a buyer's decision include age and stage in the life cycle, occupation and economic circumstances, personality and self-concept, and lifestyle and values. Psychological factors is a person's purchase choice is influenced by four main psychological factors, namely motivation, perception, learning, and beliefs and attitudes.

\section{Online Shopping}

Online shopping or also known as internet shopping or internet buying is the process of purchasing products or services via the internet (Prabowo \& Suwarsi, 2009). Shopping activities can be measured by the amount of time spent shopping, shopping frequency, and the amount of money spent for shopping (Magie \& Anna, 2008). Consumer can search and compare products or services that match the wishes and abilities of these consumers. They also use internet facilities to search for information about the products they want (Sudjanarti et al., 2018). Previous research on consumers' shopping orientations in the context of Internet shopping indicated that consumers who had distinct shopping orientations had different shopping behaviours while shopping online (Seock \& Bailey, 2008). Swaminathan et al., (1999) also found that convenience shoppers tended to use the internet more frequently to purchase goods and spent more money on their Internet purchases. However, Rowley, (1996) argued that consumers who enjoy the shopping process are unlikely to buy online because purchasing via the Internet is a poor substitution for the leisure experience associated with traditional shopping at physical stores.

\section{Lifestyle}

A lifestyle is a person pattern of living in the world as expressed in activities, interests, and opinions. It portrays the whole person interacting with his or her 
environment (Kotler \& Keller, 2016). People from the same subculture, social class, and occupation may adopt quite different lifestyles. In marketing, lifestyles are named psychographics, which include consumers' activities, interests, and opinions. Activities about how a consumer spends time such as working, vacationing, or doing other activities. Interest relates to the choice or interest of consumers in things such as houses, fashion or food and opinion a related to how consumers view a problem, event, education and future. In consumer research, psychographics consists of creating statements and asking respondents to indicate their level of agreement or disagreement with each statement.

Psychographic variables include buying patterns, opinions about consumption and social issues, values, hobbies, leisure activities, and many other dimensions. Psychographics are versatile, loosely-defined, and together with demographics; provide marketers with richly descriptive profiles of target markets (Schiffman \& Wisenblit, 2019). Psychographic segmentation is also often referred to as lifestyle analysis because it can help identify promising consumer segments, especially those related to consumer personality and attitudes. Marketers search for relationships between their products and lifestyle groups (Kotler \& Keller, 2016).

\section{Gender}

Gender is related to the socialization given to women and men. Women and men are distinguished on the basis of appropriateness and then a label is attached to each type to distinguish (Murniati, 2004). The concept of gender is an inherent trait of men and women who are constructed both socially and culturally (Murniati, 2004). Women are known as motherly creatures while men are considered strong and rational (Handayani et al., 2001). Therefore, gender can be interpreted as a social concept that distinguishes roles between men and women. The differences in functions and roles between men and women are not determined because between the two there are biological and natural differences, but are differentiated or sorted according to their respective positions, functions and roles in various fields of life and development (Handayani et al., 2001).

According to the theory of gender socialization, a behaviour is determined by the process of socialization in which individuals are shaped by cultural norms and values that are expected of a particular gender (Martiyanti, 2015). Men and women have different attitudes and behaviours, this is based on their genetic and different socialization processes. For example, women tend to be more communal minded and pay attention to everything in a new environment. Men tend to be more expressive and goal-directed and tend to focus on the part of the environment that helps them achieve their goals. Research studies show that men should often be invited to touch the product, while women often take the product without being encouraged (Kotler \& Keller, 2016).

Gender is another important factor affecting consumers online shopping behaviours. Seock \& Bailey,(2008) research has indicated that gender is a discriminating factor in the frequency of online shopping, probability to shop online and attitude towards online shopping (Rodgers \& Harris, 2003). According to 
(Bakewell \& Mitchell, 2003) states that gender is a socially constructed difference in habits or behavior between men and women. Men and women want different products and they have different ways of thinking to get the products their wants. Many products and services are inherently designed for either males or females, but gender roles have blurred, and gender is no longer an accurate way to distinguish among consumers in some product categories (Schiffman \& Wisenblit, 2019).

This practice reflects a widely held view that gender is fundamental to understand and predicting shopping behavior (Bakewell \& Mitchell, 2003). One study that focuses on gender difference, concluded that women hold diametrically opposed value regarding effective shopping compared with men. In essence, these difference manifested in terms of the time spent browsing and researching choice. Women enjoyed the process and were happy to spend considerable time and mental energy, while men sough to buy quickly and avoid it a much as possible (Bakewell \& Mitchell, 2003). In extensive review of online shopping literature by Chang et al., (2005) shows that more men than women buying online in some studies and no significant gender differences in online shopping behavior between the genders in other studies.

\section{Hyphothesis}

Lifestyle is a person pattern of living in the world as expressed in activities, interest, and opinions. There are differences in lifestyle both in term activity, interest and opinion between men and women in online shopping. For example, women enjoyed the process and were happy to spend considerable time and mental energy in online shopping, while men sough to buy quickly and avoid it a much as possible (Bakewell \& Mitchell, 2003). Furthermore, male are more interest in computers and electronics are amply available and can be easily purchased online, whereas females are more interest such as food, home decor, and clothing. There are several lifestyle differences between men and women in online shopping, so in this study interested in conducting different test of lifestyle between men and women in online shopping. Based on the explanation, the hypothesis in this study is there are gender difference between men and women on online shopping lifestyle at Padang City.

\section{Method}

This study was conducted to examine the gender difference test between men and women on online shopping lifestyle at Padang City. This type of research is a comparative research. The method used in this study is a quantitative method. This study is univariate study where the variable in this study is only one variable, namely lifestyle to find out whether or not there is an average difference between the two sample groups between men and women, the average difference test uses the independent samples t-test. 
This research was conducted to compare the similarities and differences of two or more facts and properties of the object being studied based on a certain framework of thought. The sampling technique used purposive sampling. The total sample in this study was 100 respondents. The questions in this study consist of 14 statement item. The samples in this study were men and women consumers who have shopped online for at least the last six months.

\section{Result and Discussion}

Validity test is used to measure the accuracy of a measuring instrument in performing its function. An instrument is considered valid if it is able to measure what it wants to measure. Validity is extent to which a measure or set of measure correctly represents the concept of study the degree to which it is free from any systematic or nonrandom error. Validity is concerned with how tell the concept is defined by measure (Hair et al., 2010). Based on the results of validity test using a confirmatory factor analysis (with a minimum factor loading limit of 0,50). From 14 items, there are three items not valid $(\mathrm{O} 1, \mathrm{O} 2, \mathrm{O} 4)$ that having a loading factor below. So that items not used or elimination from the questionnaire statement.

Reliability related to the consistency of the measure. Reliability is extent to which a variable or set of variables in consistent in what it is intended to measure ( Hair et al., 2010). The reliability test used is by looking at the Cronbach Alpha value. A factor is declared reliable if it has an alpha coefficient $>0.70$. From the results of the reliability test, it can be seen that the value of Cronbach's alpha 0,875>0.60, It can be concluded that the variable are reliable and can be used for research. The following are the results of the validity test and reliability test:

Table 1. Results of Validity Test and Reliability Test

\begin{tabular}{ccc}
\hline Item & Factor loading & $\begin{array}{c}\text { Cronbach's } \\
\text { Alpha }\end{array}$ \\
\hline A1 & 0,607 & \\
A2 & 0,583 & \\
A3 & 0,603 & \\
A4 & 0,617 & \\
M1 & 0,739 & 0,875 \\
M2 & 0,716 & \\
M3 & 0,786 & \\
M4 & 0,772 & \\
M5 & 0,694 & \\
O3 & 0,735 & \\
O5 & 0,550 & \\
\hline
\end{tabular}

Source: Data Processed, 2021 


\section{Hypothesis Testing}

Hypothesis testing is to determine analysis of gender difference between men and women on online shopping lifestyle at Padang City. This study uses an independent sample t-test analysis used to determine whether or not there is a difference in mean between two groups of unrelated samples. The basic assumption that must be met is the similarity of variance (homogeneity). The first step is variance similarity test (homogeneity) was carried out with the F test (Levene's Test). If the variance is the same, the t-test uses Equal Variances Assumed and if the variance is different using Equal Variances Not Assumed, the steps to test the similarity of variance (homogeneity) with the F test as follows:

Ho : accepted if Fsig $>0.05$, it means that both variants are the same

Ha : rejected if Fsig $<0.05$, it means that the two variants are different

Tabel 2. The result of Independent Samples T-test

\begin{tabular}{|c|c|c|c|}
\hline \multicolumn{4}{|c|}{ Independent Samples Test } \\
\hline & & \multicolumn{2}{|c|}{ Lifestyle } \\
\hline & & $\begin{array}{l}\text { Equal } \\
\text { variances } \\
\text { assumed }\end{array}$ & $\begin{array}{l}\text { Equal } \\
\text { variances } \\
\text { not } \\
\text { assumed }\end{array}$ \\
\hline Levene's Test for & $\mathrm{F}$ & 0.202 & \\
\hline $\begin{array}{l}\text { Equality of } \\
\text { Variances }\end{array}$ & Sig & 0,654 & \\
\hline t-test for Equality of & $\mathrm{T}$ & 0,772 & 0,772 \\
\hline Means & Df & 98 & 96,943 \\
\hline & Sig. (2-tailed) & 0,442 & 0,442 \\
\hline & Mean Difference & 0,10364 & 0,10364 \\
\hline & Std. Error Difference & 0,13422 & 0,13422 \\
\hline & $95 \%$ Confidence Interval of & $-0,16271$ & $-0,16275$ \\
\hline & $\begin{array}{l}\text { Lower the Difference } \\
\text { Upper }\end{array}$ & 0,36998 & 0,37002 \\
\hline
\end{tabular}

Source: Data Processed, 2021

Based on table 2, it is known that the value of F sig $(0.654)>0.05$. So, it means that both variants are the same, thus the model used in the $t$-test (independent sample t-test) is equal variance assumed. Based on hypothesis testing using Independent samples t-test. It known that $\mathrm{t}$ sig value in the two-side test is 0.442 , when compared with $a=0,05$, then $t$ sig $(0.0442 .>0.05)$, it means that there is no significant difference between gender. Based on the results of the independent sample $t$ test, the study showed that there are no significant difference between men and women on online shopping lifestyle at Padang City with a comparison of $t$ sig $(0.442)>0.05)$.. So it can be conclude that the lifestyle between men and women on online shopping lifestyle at Padang City is the same. 
The following explain the mean difference between men and women on online shopping lifestyle at Padang City can be seen on Table 3 below:

\section{Tabel 3. Group Statistics}

\begin{tabular}{llcccc}
\hline & Gender & N & Mean & Std. Deviation & Std. Error Mean \\
\hline \multirow{2}{*}{ Lifestyle } & Men & 50 & 3,665 & 0,7052 & 0,0997 \\
& Women & 50 & 3,561 & 0,6350 & 0,0898 \\
\hline
\end{tabular}

Source: Data Processed, 2021

From table 3 , it can be seen that mean value for men is 3.665 while and for women is 3.561. This means that mean value men is higher than women, but the difference is not so significant. The average difference between the two groups (mean value) is only 0.1036 , ranging between -0.1627 and 0.36998 . This is in accordance with (Rodgers \& Harris, 2003) that the number of Internet users is equally divided among the genders, more men than women engage in online shopping and make online purchases.

Based on the result of this study shows that there are no significant difference between men and women lifestyles in terms of activities, interests and opinions on online shopping at Padang City. It means that the hypothesis in this study is rejected. The results of this study are different from the results of research (Rodgers \& Harris, $\underline{2003}$ ) states that gender is a socially constructed difference in habits or behavior between men and women. However, the results of this study are consistent with the results of (Chang et al., 2005) shows that more men than women buying online in some studies and no significant gender differences in online shopping behavior between the genders. The results of this study are also supported by Lestari, (2015) showing that there is no significant difference in male or female informants related to the purchase of necessities that they needs. Both male and female they usually buy online fashion items such as shoes, pants, clothes, to books and cellphones, all of which can be obtained online. Furthermore, based on this research, it show that between men and women have almost the same online shopping lifestyle. This support from the result of this study that majority of respondents both men and women bought fashion products and they need convenience in online shopping practically and quickly.

\section{Conclusion}

Based on the results and discussion of this study, it can be concluded that there is no gender differences between men and women in online shopping lifestyles at Padang City. So, it can be said that the lifestyles of men and women consumers in online shopping at Padang City are the same. This is probably because at the present time, especially during the current pandemic, many consumers, both men and women, prefer to shop online rather than offline because it is more practical, fast and easy. It makes it easier for consumers to fulfill that their needs and wants.

Future research is expected to use large sample that remember that research at Padang City. It is hope for future research will examine other variables related to gender such as impulse buying and perceived risk. It also hoped for company to give 
online excellent service for customer both men and women to fulfill their wants and needs.

\section{References}

Bakewell, C., \& Mitchell, V. W. (2003). Generation Y female consumer decisionmaking styles. International Journal of Retail $\mathcal{E}$ Distribution Management, 31(2), 95106. https://doi.org/10.1108/09590550310461994

Chang, M. K., Cheung, W., \& Lai, V. S. (2005). Literature derived reference models for the adoption of online shopping. Information $\mathcal{E}$ Management, 42(4), 543-559. https://doi.org/10.1016/j.im.2004.02.006

Cyr, D., \& Bonanni, C. (2005). Gender and website design in e-business. International Journal of Electronic Business, 3(6), 565. https:/ / doi.org/10.1504/ijeb.2005.008536

Daryanto, \& Ismanto, S. (2014). Konsumen dan Pelayanan Prima. Gava Media.

Dittmar, H., Long, K., \& Meek, R. (2004). Buying on the Internet: Gender Differences in On-line and Conventional Buying Motivations. Sex Roles, 50(5-6), 423-444.

Fatmawati, N. (2020). Gaya Hidup Mahasiswa Akibat Adanya Online Shop. Jurnal Pendidikan Ilmu Sosial, 29(1), 29-38. https:/ / doi.org/10.17509/jpis.v29i1.23722

Hair, J., Black, W. C., Babin, B. J., \& Anderson, R. E. (2010). Multivariate Data Analysis (Seventh Ed).

Handayani, Trisakti, \& Sugiarti. (2001). Konsep dan Teknik Penelitian Gender. Pusat Studi Wanita dan Kemasyarakatan.

Hasan, B. (2010). Exploring gender differences in online shopping attitude. Computers in Human Behavior, 26(4), 597-601. https:/ / doi.org/10.1016/j.chb.2009.12.012

Kotler, P., \& Keller, K. L. (2016). Marketing Management. In Marketing Management (15theditio ed.). Pearson Education.

Lestari, S. B. (2015). Shopping Online Sebagai Gaya Hidup. Jurnal Ilmu Sosial, 14(2), 24-41.

Lim, Y. M., Yap, C. S., \& Lau, T. C. (2010). Online Search and Buying Behaviour: Malaysia Experience. Canadian Social Science, 6(4), 154-166.

Magie, \& Anna Ashlock. (2008). An Analysis of Lifestyle, Shopping Orientations, Shopping Behaviors and Shopping Involvement Among Teens Aged 13 to 18 in The United States. ProQuest Dissertations and Theses.

Martiyanti, D. (2015). Perbedaan Gender Mengenai Perceived Risk Pada Pembelian Online. $\quad$ Kinerja, 140-149. https:/ / media.neliti.com/media/publications/143556-ID-perbedaan-gendermengenai-perceived-risk.pdf

Murniati, N. (2004). Getar Gender, Buku Peratama (Perempuan Indonesia dalam Perspektif Sosial,Ekonomi, Politik, Hukum dan HAM). Indonesiatera.

Prabowo, \& Suwarsi. (2009). Pengaruh Shopping Orientation dan Gender Differences pada Online Information Search dan Online purchase. Fokus Manajerial, 7(2).

Rodgers, S., \& Harris, M. A. (2003). Gender and E-commerce: An exploratory study. Journal of Advertising Research, 43(3), 322-329. https:/ / doi.org/10.1017/S0021849903030307

Rowley, J. (1996). Retailing and shopping. International Journal of Retail $\mathcal{E}$ Distribution 
Management, 24(3), 26-37.

Schiffman, L. G., \& Wisenblit, J. (2019). Consumer Behavior 12th Edition (twelfth ed). Pearson Education.

Seock, Y. K., \& Bailey, L. R. (2008). The influence of college students' shopping orientations and gender differences on online information searches and purchase behaviours. International Journal of Consumer Studies, 32(2), 113-121. https:/ / doi.org/10.1111/j.1470-6431.2007.00647.x

Shih, H. P. (2004). An empirical study on predicting user acceptance of e-shopping on the Web. Information and Management, 41(3), 351-368. https:/ / doi.org/10.1016/S0378-7206(03)00079-X

Slyke, C. Van, Christie, L. C., \& Belanger, F. (2002). Gender Differences in Perceptions of Web Based Shopping. Communication of The Acm, 45(7), 82-86.

Sudjanarti, D., Khabibah, U., \& Wardani, T. I. (2018). Terhadap Pencarian Informasi Online Dan Belanja Online Pada Mahasiswa Jurusan Administrasi Niaga. Jurnal Administrasi Dan Bisnis, 12(2).

Swaminathan, V., Lepkowska-White, E., \& Rao, B. (1999). Browser or buyer in cyberspace? An investigation of factor influencing electronic exchange. Journal of Computer Mediated Communication.

Zhou, L., Dai, L., \& Dongsong, Z. (2007). Online Shopping acceptance Model, A Critical Survey of Consumer Factors In Online Shopping. Journal of Electronic Commerce Research, 8(1), 41-62. https:/ / doi.org/10.1109/EMBC.2014.6944802 